\title{
一般口演 9
}

\section{上喉頭神経刺激による口腔感覚の変調}

\section{Modulation of Oral Sensation during Electrical Stimulation of the Superior Laryngeal Nerve}

○酒井翔悟, 辻 光順, 真柄 仁, 辻村恭憲, 井上 誠

Shogo Sakai, Kojun Tsuji, Jin Magara, Takanori Tsujimura, Makoto Inoue

新潟大学大学院医歯学総合研究科摂食嚥下リハビリテーション学分野

Division of Dysphagia Rehabilitation, Niigata University Graduate School of Medical and Dental Sciences

\section{I. 目的}

低閾值誘発性の開口反射は咀嚼中に抑制を受けること が知られており。これまで我々は，與下を生じさせる目 的で上喉頭神経を電気刺激した際に開口反射が抑制され ることを報告してきた。このことから開口反射経路のい ずれかの領域で上喉頭神経刺激時に抑制性の入力が存在 することが考えられたが，詳細なメカニズムは不明であ る。本研究は, 上喉頭神経刺激時における開口反射の変 調のメカニズムを解明することを目的として, 下歯槽神 経刺激に応答する脳幹の神経活動を記録し, 上喉頭神経 刺激時にいかなる抑制が認められるかについて調べた.

\section{II. 方 法}

\section{1. 動物}

$2.5-3.0 \mathrm{~kg}$ の雄性ウサギを使用し, ウレタン麻酔下 $(1.0 \mathrm{~g} / \mathrm{kg}$, iv) にて実験を行った.

\section{2. 刺激}

下歯槽神経の電気刺激（パルス時間 0.2 ミリ秒, $2 \mathrm{~Hz}$ ) を行い開口反射が生じることを確認した後に，タングス テン電極 $(2 \sim 5 \mathrm{M} \Omega)$ を使用して同刺激に応答する脳 幹三叉神経核領域の単一ニューロン活動を記録した。ま た嚥下誘発のために上喉頭神経への連続電気刺激 $(2 / 4$ $\mathrm{T}$ ，パルス時間 0.2 ミリ秒， $30 \mathrm{~Hz}$ ）を実施した。脳幹の 記録部位は，下歯槽神経刺激に対して $1.5 \sim 4.0$ ミリ秒以 上の潜時でニューロンの応答があるものとし，記録後に は50 $\mu \mathrm{A}$ 以下の直接刺激（パルス時間 0.2 ミリ秒, $2 \mathrm{~Hz}$ ) にて顎二腹筋での筋電位誘発の有無を確認した。

\section{3. 記録}

開口反射・嚥下反射記録のために顎二腹筋および顎舌
骨筋に係留したワイヤー電極により笳活動電位を導出し た。記録部位は，記録終了後に電気凝固し，摘出した脳 幹を $10 \%$ ホルマリンにて固定後，ミクロトームを用い て $50 \mu \mathrm{m}$ ずつの凍結切片を作製し, 刺激部位を組織学 的に確認した。

\section{4. 解析}

下歯槽神経刺激を 30 秒間，上喉頭神経刺激を 10 秒 間行い, 上喉頭神経刺激前 - 中 · 後 (Control, Stim, Post）での単一ニューロン活動（誘発頻度，潜時および 潜時の延長）を比較した。潜時の延長は，上喉頭神経 刺激時 (Stim) および刺激後 (Post) の潜時から刺激前 (Control) を減じたものとした.

\section{III. 結果及び考察}

下歯槽神経刺激に応答する単一ニューロン記録にお いて，上喉頭神経 $2 \mathrm{~T} \cdot 4 \mathrm{~T}$ 刺激時 (Stim) および刺激 後 (Post) に誘発頻度が低下するものが観察され，また Control と比較し潜時が統計学的に有意に延長したもの が多数認められた。誘発頻度の低下および潜時の延長 は，上喉頭神経 $2 \mathrm{~T}$ と比較し，4 $\mathrm{T}$ 刺激時に多くみられ た。単一ニューロンが誘発される下歯槽神経刺激の強度 は，開口反射の誘発閾值よりも小さいものがほとんどで あった。これらの結果から，下歯槽神経支配領域の口腔 内感覚入力が上喉頭神経刺激によって変調を受けること が明らかとなった。

また, Control の潜時が長い程誘発頻度が低下する傾

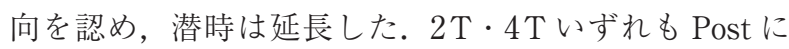
おいて潜時の延長したニューロンを多く認めた。このこ とから, 抑制が生じている領域として, 求心性神経にお けるシナプス前領域，2次ニューロン，多シナプスを介 


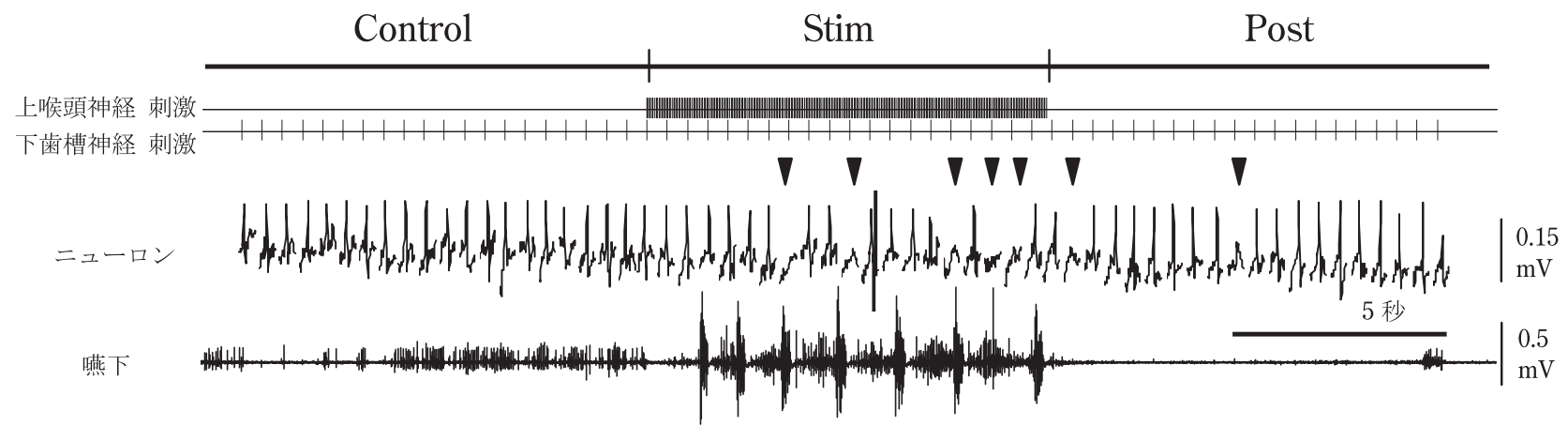

図 1 下歯槽神経刺激に応答する単一ニューロンの記録例

単一ニューロンが，上喉頭神経の刺激中および刺激後に消失した（矢印）.

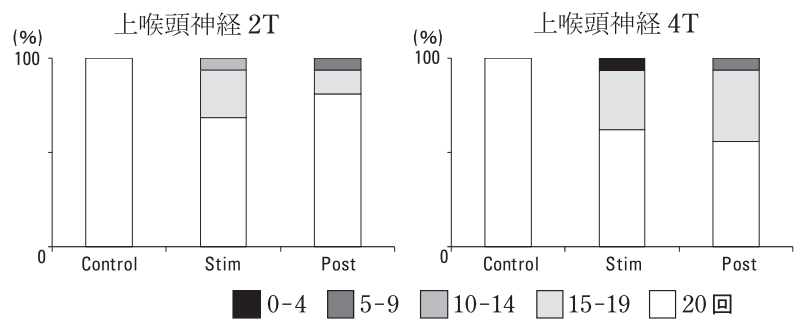

図 2 下歯槽神経刺激によって誘発された単一ニューロンの上 喉頭神経刺激時および刺激後の誘発頻度の数の割合 上喉頭神経刺激強度が大きいもの程誘発頻度の低下を示 す傾向を認めた.

した開口反射の最短経路ではないニューロンレベルであ る可能性が考えられ，また上喉頭神経刺激により変調を 受けるニューロンは三叉神経核領域に広く分布している ことが示唆された。単一ニューロンの記録部位は, 三叉 神経主感覚核・春髄路核吻側亜核等, 三叉神経核内で多 くのものが確認された.

今回の結果から, 下歯槽神経支配領域からの口腔内感 覚入力は上喉頭神経刺激によって抑制を受けることが示 され，記録されたニューロンが脳幹の三叉神経核領域に 近接していたことから, 上喉頭神経刺激時における開 口反射の変調が同領域で生じている可能性が考えられ た。また上喉頭神経刺激後にも抑制効果が持続してい たことから，與下 CPG 介在ニューロンの活性化による Aftereffect が関与していたことが考えられた。
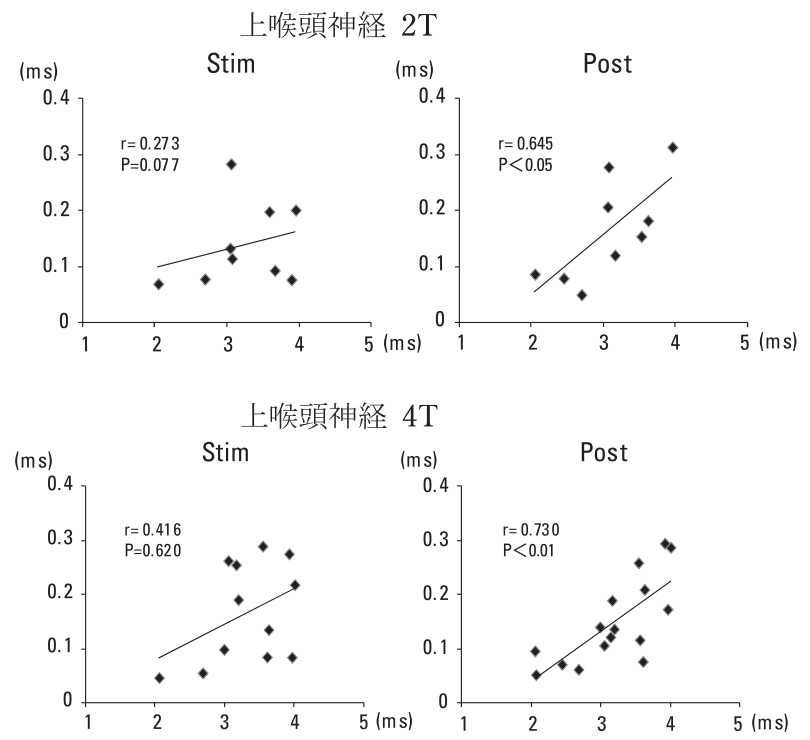

図 3 単一ニューロンの潜時と潜時の延長の相関 $\mathrm{X}$ 軸：Control の潜時 Y 軸：潜時の延長 Control の潜時が大きいもの程上喉頭神経刺激によって 潜時が延長する傾向を認めた.

\section{N． 参考文献}

1 ) Fukuhara et al: Effects of electrical stimulation of the superior laryngeal nerve on the jaw- opening reflex. Brain Research 2011; 1391: 44-53.

2 ) K.A. Olsson et al: modulation of transmission in rostral trigeminal sensory nuclei during chewing. J Neurophysiol. 1986 Jan; 55 (1): 56-75 